\title{
Entrepreneurs' attitude on Key Success Factors of Thai firms Towards ASEAN Economic Community: The case of Thai rice export
}

\author{
KulachetMongkol \\ College of Graduate Study in Management, KhonKaen University, Thailand
}

\begin{abstract}
Rice is known as one of significant economic plants of Thailand, and is a major source of country's economic income. In 2016, rice industry becomes more competitive regarding the establishment of The ASEAN Economic Community (AEC). It is very important for entrepreneurs to prepare themselves and their firms in order to be successful in the industry. Thus, this research aimed to study entrepreneurs' attitude on factors supporting the growth of Thai rice export business. The sample group was 40 companies which were selected by the probability sampling method. Questionnaires were used as a research instrument while regression analysis was used as a statistical tool for the hypothesis testing. The findings showed that key success factors such as product quality, adequate market research, price advantage, local partnership, and cross cultural understanding had significant influence on the entrepreneurs' attitude towards the growth of export business of rice after the integration of the ASEAN Economic Community (AEC). In conclusion, it is also found that private firms need more support from the Thai government.
\end{abstract}

Keywords:Rice, Key Success factors, ASEAN Economic Community.

\section{Introduction}

Rice is known as an economically valuable plant that generates largeincome for Thailand, the country which has a strong tradition of rice production. It has the fifth-largest amount of land under rice cultivation in the world and is the world's second largest exporter of rice [1]. Thailand has plans to further increase the land available for rice production, with a goal of adding 500,000 hectares to its already 9.2 million hectares of rice-growing areas The Thai Ministry of Agriculture expects rice production to yield around 25 million tonnes of paddy rice in the 2016-2017 crop year, down from 27.06 million tonnes in 2015-2016 [2]. Jasmine rice, a higher quality type of rice, is the rice strain most produced in Thailand. Jasmine has a significantly lower yield rate than other types of rice, but it normally fetches more than double the price of other strains on the global market [3]. Nevertheless, a very significant change has just begun in 2015 deal to the creation of the ASEAN Economic Community (AEC), Thai rice entrepreneurs need to prepare themselves for the upcoming changes by having good consultants, making connections, learning about entrepreneurship and related industries [4]. Therefore, this study focuses on Entrepreneurs' attitude on Key Success Factors of Thai firms Towards ASEAN Economic Community: The case of Thai rice export, and results of the study could be used and applied to increase the development of the Thai rice export industry for global reach.

Objectives of the Study

- To study entrepreneurs' attitude towards the growth of Thai rice export after the integration of the ASEAN Economic Community (AEC).

- To study key success factors which influence the entrepreneurs' attitude towards the growth of Thai rice export after the integration of the ASEAN Economic Community (AEC).

\section{Relevant Concepts and Theories}

Two significant concepts and theories have mainly been focused in this research. Firstly, it focuses on key success factors concepts which have been explained by various scholars. For instance, Sa and Hambrick [5] pointed out that the differing industries have different success factors, and that companies that have those 
success factors will be successful. Strong prediction of key success factors in different environments is provided by atypology of mature industrial-product industries which have been organized according to their transaction complexity and core technology [6]. In the similar vein, Cullen and Parboteeah [7] contended that factors that lead to success in an industry are called key success factors (KSFs). Each one of these factors can have different degrees of importance in different industries or within the same industry at different point in time. An analysis of an industry helps management to identify the important characteristics of companies, products or services that lead to competitive success. In addition, Boynlon and Zmud [8] also pointed out that key success factors were those few things that must go well to ensure success for a manager or an organization, and, therefore, they represent those managerial or enterprise area, that must be given special and continual attention to bring about high performance. KSFs included issues vital to an organization's current operating activities and to its future success. At this point, it can be concluded that KSFs could consist of quality, innovation, corporate social responsibility, human capital, financial capital, and etc. Finally, key success factors (KSFs)concept from Daniel [9] was examined and applied to be variables in this research framework since he has been using his KSF concept as a business tool in order to improve firms' competitiveness [4].

Secondly, the research focused on the creation of ASEAN Economic Community (AEC) since it was believed that AEC would help country members to develop their economies as well as helping their entrepreneurs to have more opportunities in terms of doing their business across the region [4]. To illustrate the point, The ASEAN Economic Community is the goal of regional economic integration in 2015. Its characteristics include: (1) a single market and production base, (2) a highly competitive economic region, (3) a region of fair economic development, (4) a region fully integrated into the global economy. The areas of cooperation include human resources development; recognition of professional qualifications; closer consultation on macroeconomic and financial policies; trade financing measures; enhanced infrastructure and communications connectivity; development of electronic transactions through e-ASEAN; integrating industries across the region to promote regional sourcing; and enhancing private sector involvement. Through the free movement of skilled labor, goods, services and investment, ASEAN will rise globally as one market with each member gaining from each other's strengths, thus increasing its competitiveness and opportunities for development [10].

\section{Methodology}

This is a survey research on Entrepreneurs' attitude on key success factors of Thai firms towards ASEAN Economic Community. Both primary and secondary sources were examined as research data.

\subsection{Population and Samples}

The study population consisted of 556 Thai entrepreneurs who were owners of rice export firms, and have been listed by the Office of Commodity Standards, Thailand. However, only 40 potential entrepreneurs were selected as a sample group by purposive sampling technique [11], [12] and they have been contacted and interviewed through telephone.

\subsection{Creating Research Tool}

The research tool was created in a form of questionnaires following the steps below:

- Research tools were handed out to 5 specialists to verify the content validity by identifying the Index of Item Objective Congruence (IOC) by choosing questions with the index of higher than 0.50 [13].

- The reliability analysis was done by determining Cronbach Alpha. The value of Cronbach Alpha was 0.855 for the question concerning the entrepreneurs' attitude towards the growth of Thai rice export after the integration of the AEC. 


\section{Data Analysis}

Descriptive Statistics was a method used for general analysis on respondents, i.e. percentage, measures of central tendency such as mean, measures of dispersion such as standard deviation while simple regression, an inferential statistics was a method used to test the research hypothesis.

\section{Conclusions}

The study found that the majority of respondents (40.6 percent) exported jasmine rice to China, and their firms approximately had production capacity more than 50,001 tons per year (39 percent).

In relation to the key success factors (KSFs) which influenced the entrepreneurs' attitude towards the growth of the Thai rice export after the integration of the ASEAN Economic Community (AEC),

The results showed that KSFs consisted of capital and technology,production quality and delivery time,brand and product design. Furthermore, entrepreneurs believe that AEC would help them to easily access to new customers across the region.

According to entrepreneurs' attitude on the growth of their businesses, they were confident that AEC would stimulate the growth of Thai rice industry $(\bar{x}=4.08$, S.D. $=0.731)$. In addition, they also believed that AEC would help them to increase their production capability as well as helping them to increase their production bases $(\bar{x}$ $=3.99$, S.D. $=0.627$ ).

Hypothesis Testing Results

Critical factors had significant influence on the entrepreneurs' attitude towards the growth of Thai export rice after the integration of the ASEAN Economic Community (AEC).

\begin{tabular}{lcc}
\multicolumn{3}{c}{ TABLE I: Hypothesis Testing } \\
\hline \hline Variable & $\begin{array}{c}\text { Unstandardized } \\
\text { Coefficients (B) }\end{array}$ & Sig \\
\hline Constant & 1.245 & $.000^{*}$ \\
* Sitical Success Factors & 0.822 & $.000^{*}$ \\
\hline Significant level at 0.05 & &
\end{tabular}

From the table I, it was found that critical factors had significant influence on the entrepreneurs' attitude towards the growth of Thai rice export after the integration of the AEC, and simple linear equation could be created as $\mathrm{Y}=1.245+0.822 \mathrm{X} 1$; supposed $\mathrm{X} 1$ represented the critical factors and the critical factors coefficient (Z) equals to 0.755

\section{Discussion}

From the research "Entrepreneurs' attitude on key Success factors of Thai firms towards ASEAN Economic Community: The case of Thai rice export", entrepreneurs believed that their companies were able to find new customers instantly, and transported their product to them on time. Moreover, companies had the trademark which promoted their image, and this in line with Daniel [9], Boynlon and Zmud's idea which defined that key success factor is the term for an element that is necessary for an organization or project to achieve its mission [4].

Entrepreneurs' attitudes towards the growth of the Thai rice export industry after joining ASEAN were that the opportunities for higher level of production, the expansion of production base and distribution channels, including the government policies which supported firms to reduce export taxes. Moreover, it would enhance Thai economic growth and entrepreneurs' abilities [14]. This also conformed to Mongkol [4] and Tepprasit's research [15] which said that learning and analyzing business, solving problem, and studying related industries would help entrepreneurs to prepare themselves to enter AEC efficiently.

In relation to the hypothesis testing, the results showed that the competitive ability and key success factors influenced entrepreneurs' attitudes towards the growth of the Thai rice export industry after joining ASEAN economic community. Moreover, if entrepreneurs could bring out and utilize advantages from internal and 
external factors to run their business, their firms would be able to create business opportunities and sustainable competitive advantages.

Additionally, determining success indicators of industrial business such as capital, quality, service, and punctuality, had an effect on the competitive ability and business achievement simultaneously [9]. It also conforms to Mongkol's research [4] which indicated that the success of the Thai exporting industry derived from the competitiveness of local firms in the upstream industry and the leadership of foreign firms in the downstream sector. The factors that strengthen this competiveness were innovation and technology absorption.

\section{Suggestions from This Research}

Since the critical success factors influence entrepreneurs' attitudes towards the growth of the Thai rice export industry after joining AEC, the researcher has suggestions about strategic development and management for rice export industry as follows:

- Entrepreneurs had strong opinion about the cost, manufacturing technology, quality of production standard, and brand design; thus, entrepreneurs should add modern and standard manufacturing technology to their production processes in order to support increasing demand of rice. Furthermore, they should look for a particular support from related Thai government agencies as well.

\section{Suggestions for Future Research}

- A qualitative study could help a research to explore in-depth entrepreneurs'attitude.

- The conceptual framework of this research can be applied to different types of industries.

\section{References}

[1] A. Maierbrugger. (February 2013). Thailand Wants Rice Top Spot Back. [Online]. Available: http://investvine.com/thailand-wants-rice-top-spot-back/.

[2] Reuters. (2016). "Thailand aims for $25 \mathrm{mln} \mathrm{T}$ rice paddy output 2016-17, down on yr. [Online]. Available: http://af.reuters.com/article/commoditiesNews/idAFL3N1523DM

[3] The Nation. (2008). Rice strain is cause of comparatively low productivity. [Online]. Available: http://www.nationmultimedia.com/2008/04/16/opinion/opinion_30070831.php.

[4] K. Mongkol, "Critical factors supporting Thai firms towards", Asean Economic Community: The Case of Thai Rubber Export, International Conference on Business Law and Corporate Social Responsibility (ICBLCSR'14), Phuket, Thailand Oct 1-2, 2014.

[5] Sa, J.A.S.D.V.E and D.C. Hambrick, "Key Success Factors: Test of a General Theory in the Mature Industrial-Product Sector," Strategic Management Journal, Vol. 10(4), pp367-82, 1989. http://dx.doi.org/10.1002/smj.4250100406

[6] C. Tanchotsrinon, "The Analysis of Key Success Factors that Leads to Success in Exporting Thai Mangoes to Japan," Independent Study, Graduate School, Kasetsart Univ., Thailand, 2010.

[7] J.B. Cullen and K.P. Parboteeah, "Multinational Management: A Strategic Approach," $4^{\text {th }}$ ed, Mason, OH: Thomson South Western, 2008.

[8] A.C. Boynlon, and R.W. Zmud, "An Assessment of Critical Success Factors," Sloan Management Review, Vol.25:4, pp. 17-27, 1984.

[9] R. Daniel, "Management Information Crisis," Harvard Business Review, Vol.39, No.5, pp. 111-121, September October, 1961.

[10] Local Government Academy of the Philippines. "Rising as One: The Filipino Nation Towards the ASEAN Economic Integration," 2014.

[11] W.G. Zikmund, “Business Research Methods,”7ed. California: Thompson South - Western, 2003. 
[12] T. Siljaru, "Research and Statistical Analysis by SPSS and AMOS," Bangkok: Business R\&D Partnership, 2012.

[13] T. Pongpaew, “Thesis Writing,”Research and Training Institute. Mahasarakham, 2008.

[14] P. Ketpan, T. Mekhora, and P. Munkep, "Factors influencing the success of Thai Green Roselle Exporting," King Mongkut's Agricultural Journal.30:3, pp. 1-12, 2012.

[15] P. Tepprasit, "The preparation of Thai Entrepreneurs towards ASEAN Economic Community: The case of Thailand, Vietnam, Malaysia, and Indonesia," National Conference on Business and Economics. $6^{\text {th }}$, Faculty of Management Science, KhonKaen University, 2013. 